\title{
PREVALENCE AND INTENSITY OF PARASITES IN DOMESTIC DUCKS
}

\author{
SHARmin Musa*, TANia Rahman AND Hamida Khanum \\ Department of Zoology, University of Dhaka, Dhaka-1000, Bangladesh \\ Key words: Parasites, Domestic ducks, Prevalence, Intensity
}

Domestic ducks (Anas platyrhynchas Linnaeus, 1758) play a major role in rural economy in the form of meat and egg. They contribute 1642 million eggs and 163 million ton meat per year $(1999-2000)^{(1)}$ in Bangladesh. Geographical location, subtropical climatic condition, water lodged and low areas of the country are suitable for duck habitat but these factors also favor growth, multiplication, development, survival and spread of parasites. Parasitic infestation cause diseases in ducks and affect their productivity and growth ${ }^{(1)}$. There are a few reports on the incidence and prevalence of parasitic diseases of poultry in Bangladesh ${ }^{(1)}$. The major external parasites of poultry are lice, mites and ticks. Deaths resulting from infestations of external parasites are rare, but production losses often occur because of the irritation caused to the birds. For example many external parasites suck blood which often causes birds to become anaemic ${ }^{(2)}$.

Infections may cause considerable damage and great economic loss to the poultry industry due to malnutrition, decreased feed conversion ratio, weight loss, lowered egg production and death in young birds(3). In Korea, Issiki (1934)(4) made first report of intestinal parasite Echinostoma revolution from a wild bird. In Bangladesh work has been done on helminth parasite of domestic fowl where Khanum(5) and Akhtar(6) found trematode and nematode parasites in domestic fowl. A number of studies have been conducted on duck parasite by Qadir(7) and Islam et al. ${ }^{(8)}$ in Bangladesh. Most of the studies did not focus on the prevalence and intensity in detail. The present study was designed to find out the prevalence and intensity of both ecto- and endoparasites in domestic duck.

The ducks were collected from new market of Dhaka city and were brought to Parasitology Laboratory, Zoology Department, University of Dhaka. The total length $(\mathrm{cm})$ (beak to tail) and the weight $(\mathrm{g})$ were taken for each duck.

For collection of ecto-parasites, aerosol was sprayed over the feathers of the body and left for five minutes. After shaking the duck, ectoparasites (lice) fell from the feathers on the white paper and then were picked up and taken into a vial containing $70 \%$ alcohol. Specimens were cleaned with lactophenol and stained in borax carmine.

*Author for correspondence: <sharminsumi@yahoo.com>. 
For collection of endo-parasites, the gastrointestinal tract was separated and then differentiated into oesophagus, crop, proventriculus, gizzard, duodenum, small intestine, caecum and rectum, then opened by incision using binocular dissecting micoscope. Parasites were fixed and kept in $70 \%$ alcohol. A binocular dissecting microscope was used to observe and identify the parasites. The endoparasites were stained in borax carmine being cleared with lactophenol. The only clearing agent lactophenol was used for trematodes and cestodes. Collected parasites were identified according to Yamaguti ${ }^{(9,10)}$ and Soulsby ${ }^{(11)}$.

This study revealed four species of lice from the feathers and body surface and three species of helminths from the intestines of the domestic ducks. Prevalence and intensity of the parasite infestation varied from species to species of the recorded parasites and also hosts' sex and location in the organ. More parasites were recorded in the small intestine ( $80 \%$ prevalence and $19 \pm 16$ intensity) than the large intestine and caecum $(10 \%$ prevalence and $16 \pm 1$ intensity). All the female ducks (100\%) were found infected with the trematode and cestodes, while in the case of male only $60 \%$ were infected. The intensity of infections was $24.4 \pm 8$ in female ducks and $15.33 \pm 2$ in male ducks. The details are shown in Table 1.

Table 1. Prevalence and intensity of ecto- and endo-parasites in domestic ducks $(n=20)$.

\begin{tabular}{lcccc}
\hline $\begin{array}{l}\text { Name of } \\
\text { the parasite }\end{array}$ & $\begin{array}{c}\text { No. of host } \\
\text { infected }\end{array}$ & $\begin{array}{c}\text { Prevalence } \\
(\%)\end{array}$ & $\begin{array}{c}\text { Total no. } \\
\text { of parasite } \\
\text { collected }\end{array}$ & Intensity \\
\hline Lipeurus squalidus & 20 & 100 & 894 & $44.7 \pm 17.5$ \\
Gonicotes hologaster & 20 & 100 & 787 & $39.35 \pm 13.5$ \\
Menopon leucoxanthum & 16 & 80 & 599 & $37.44 \pm 16.5$ \\
Menacanthus stramineus & 12 & 60 & 230 & $19.17 \pm 8.5$ \\
Echinostoma revolutum (Trematode) & 6 & 30 & 39 & $6.5 \pm 2.5$ \\
Cotugnia cuneata (Cestode) & 4 & 20 & 68 & $17 \pm 2.5$ \\
Hymenolepis columbae (Cestode) & 8 & 40 & 229 & $28.63 \pm 7.5$ \\
\hline
\end{tabular}

In the present study, most of the ectoparasites detected were lice. Lice causes heavy morbidity by sucking blood and also causes irritation to the birds. A few works on gut parasites of ducks have been done in Bangladesh. Qadir(7) worked on helminth parasites of domestic ducks of Mymensingh district in Bangladesh and recorded 13 species of helminths from domestic ducks. In the present study female had higher prevalence and intensity of parasite infection. This is consistent with the study of Farzana et al.(1) where they found high density of parasitic infection in female ducks compared to male. Female ducks may be more susceptible to parasitic infection due to egg laying and also lack of balanced nutrition, which affect their immune system and ability to combat the parasitic infection. Moreover, some hormonal influence may be associated with this. 
Most studies on avian parasites have reported that poultry birds tend to be more infected with cestodes. Hymenolepis columbae showed highest prevalence in the present study which is consistent with the study of Farzana et al.(1). Soulsby ${ }^{(11)}$ found thousands of hymenolepids per bird. More parasitic burden of cestodes in ducks might be explained by their scavenging feeding on vector hosts of cestodes. In the present study it was found that most helminthes were located in the small intestine. This is in consistence with the work of Eom and Rim ${ }^{(4)}$. In the light of present study, it may be concluded that the ducks have high prevalence of parasitic infestation. As ducks are free ranged animals they are exposed to a wide natural environment and consume a wide variety of food. They may be easily infected by different species of parasites through the ingestion of contaminated food and consumption of intermediate host which harbor the larval stages of the parasite. The present status of parasitic infestation in duck may cause serious loss of health of ducks which ultimately affect the total protein content of the domestic birds. Further study may be undertaken to control those parasites mainly by maintaining hygiene and sanitation of the domestic duck and their food.

\section{References}

1. Farzana T, KR Islam and MMH Mondal 2008. Population density of helminths in ducks: effects of host's age, sex, breed and season. Bangl. J. Vet. Med. 6(1): 45-51.

2. Graham P. 1986. Official website of Austalian government. www.primaryindustry.nt.gov.au

3. Puttalakshmamma GC, KJ Ananda, PR Prathiush, GS Mamatha and R Suguna 2008. Prevalence of Gastrointestinal parasites of Poultry in and around Banglore. Veterinary World 1(7): 201-202

4. Eom K-S and HJ Rim 1984. A study on the parasitic helminths of domestic ducks (Anas platyrhynchos var.domestica Linneaus) in Korea. The Korean J. Parasitology 22(2): 215-221.

5. Khanum H 1997. Trematode parasite Paraphostomum humairum n. sp.from doemstic fowl of Bangladesh. Journal of Bengal Natural History Society. New Series 16(2): 35-39.

6. Akhtar, H 1987. Gastrointestinal nematodes from domestic fowl. Bangladesh. J. Zool. 15(2): 155159.

7. Qadir ANMA 1979. Helminth parasites of domestic ducks (Anas boschas domesticus) of Mymensingh district, Bangladesh. Bangladesh Veterinary Journal 13: 43-45.

8. Islam MR, H Shaikh and MA Baki 1988. Prevalence and pathology of helminth parasites in domestic ducks of Bangladesh. Veterinary Parasitology 29: 73-77.

9. Yamaguti S 1958(a). Systema Helminthum.Vol1. The Digenetic Trematodes of Vertebrates. Interscience Publishers Inc.New York, USA. pp. 979.

10. Yamaguti S 1958(b). Systema Helminthum.Vol II. The Cestodes of Vertebrates. Interscience Publishers Inc.New York, USA. pp. 1575.

11. Soulsby EJL 1982. Helminths, Arthropods and Protozoa of Domesticated Animals (7th Ed). London :Baillere Tindall and Cassell Ltd. pp. 366-387. 